\title{
Mungbean Yield and Nutrients Content as Affected By Coal and Plant Based Humic Acid Application
}

Syed Ishtiaq Hyder ${ }^{1 *}$, Fayyaz Hussain ${ }^{1}$, Shahid Riaz ${ }^{1}$, Ahmad Khan ${ }^{1}$, Muhammad Arshad Ullah ${ }^{1}$, Rizwan Ahmad ${ }^{1}$, Zubair Rehman $^{2}$ and Aqeel Ahmad ${ }^{1}$

${ }^{1}$ National Agriculture Research Centre, Islamabad

${ }^{2}$ Balochistan Agriculture College, Quetta

DOI: $10.36348 /$ sijtcm.2019.v02i10.001

| Received: 01.12.2019 | Accepted: 10.12.2019 | Published: 20.12 .2019

*Corresponding author: Syed Ishtiaq Hyder

\section{Abstract}

Soil health Index demands organic fertilizer usage may be imperative couple with chemical fertilizers. Mungbean (Vigna radiata) yield and nutrients content were studied during kharif 2019 through coal and plant based humic acid (HA) application at NARC. The plots were arranged in randomized complete block design (RCBD). Results indicated that application of HA couple with chemical fertilizers significantly improved mungbean yield and nutrients content. HA at $15 \mathrm{~kg} \mathrm{ha}^{-1}$ along with $50 \mathrm{~kg} \mathrm{ha}^{-1}$ DAP recorded the highest grain yield $\left(0.79 \mathrm{t} \mathrm{ha}^{-1}\right)$ that is $14.4 \%$ more than the control $\left(0.69 \mathrm{t} \mathrm{ha}^{-1}\right)$ receiving $100 \%$ DAP application alone. The highest concentration of $\mathrm{P}(0.34 \%), \mathrm{K}(3.7 \%)$ and $\mathrm{N}(3.65 \%)$ in whole shoot mungbean were observed in the treatment where HA was applied at $15 \mathrm{~kg} \mathrm{ha}^{-1}$ along with $50 \mathrm{~kg} \mathrm{ha}^{-1} \mathrm{DAP}$. Residual organic matter improved by $0.06 \%$. Based on findings of this study it can be suggested that HA couple with inorganic fertilizer application have significant effect on grain yield and nutrients content of $\mathrm{N}$ and P. It showed that HA mayenhanced $\mathrm{NO}_{3}$ and $\mathrm{P}$ availability through chelation and reduce soil $\mathrm{P}$ fixation.

Keywords: Mungbean, Nutrients, Humic Acid.

Copyright @ 2019: This is an open-access article distributed under the terms of the Creative Commons Attribution license which permits unrestricted use, distribution, and reproduction in any medium for non-commercial use (NonCommercial, or CC-BY-NC) provided the original author and source are credited.

\section{INTRODUCTION}

Soil health is major concern in soil fertility scenario. This imbalance fertilizers use continuously damaging biological and physical properties of soil as well as nutrients and organic matter bioavailability, which result in low crop yield [1].Owing to the ever increasing cost of inorganic chemical fertilizers, the organic fertilizers like humic acid has become imperative for sustained crop production and maintenance of soil health [2]. Commercial Humic acid is a rich source of many essential nutrients including, 6$8 \%$ hydrogen, $46-42 \%$ oxygen, $44-58 \%$ carbon and $4-$ $5 \%$, Nitrogen, as well as many other nutrients which encourage plant growth [3]. Humic acid when applied to field converted into readily available humic substances which directly or indirectly effect the plant growth [3]. It was reported that humic substances promote the activity of PGPR to induce the growth promoting hormones in rhizospheric zone and these hormones increase the efficiency of roots to transport water and nutrients from soil solution to plants ElHassaninet al. [4]. Humic acid also act as natural antioxidant. Its presence in plant tissues affects many biochemical processes by increasing nutrient uptake and maintaining levels of amino acids and certain vitamins [5]. It was also concluded that addition of humic acid mayreduce the requirement of primary macronutrients $(\mathrm{N}, \mathrm{P}$ and $\mathrm{K})$ at optimal growth [6]. Xi et al. [7] also observe the stimulatory effect on plant micro and macronutrient uptake due to humic acid application. Keeping the declining soil fertility, ever increasing fertilizer costs and continuous increasing demand for more food the current study was initiated. The current study aimed at applying HA along with chemical fertilizers to enhance mungbean productivity.

Table-1: Physico chemical soil characteristics

\begin{tabular}{|l|l|l|}
\hline Soil characters & \multicolumn{1}{|l|}{ Unit } & Values \\
\hline Textural Class & \multicolumn{1}{|l|}{ Clay loam } \\
\hline $\mathrm{pH}$ & --------- & 7.80 \\
\hline $\mathrm{EC}(1: 1)$ & $\left.(\mathrm{dS} \mathrm{m})^{-1}\right)$ & 0.34 \\
\hline Organic Matter & $(\%)$ & 0.51 \\
\hline $\mathrm{NO}_{3}-\mathrm{N}$ & $\left(\mathrm{mg} \mathrm{kg}^{-1}\right)$ & 2.41 \\
\hline $\mathrm{K}$ & $\left(\mathrm{mg} \mathrm{kg}^{-1}\right)$ & 109 \\
\hline $\mathrm{P}$ & $\left(\mathrm{mg} \mathrm{kg}^{-1}\right)$ & 1.31 \\
\hline
\end{tabular}




\section{MATERIALS AND METHODS}

A field experiment was conducted during 2019 at pulses program, National Agricultural Research Institute (NARC) Islamabad.The latitude and longitude of Islamabad is $33^{\circ} 42^{\prime} \mathrm{N}, 73^{\circ} 10 \mathrm{E}^{\prime}$. Treatments were assigned according to RCBD design to see the effect of humic acid application. Humic substances derived from coal have characteristics of $\mathrm{pH} 7.8$, EC 0.94 and OM $68 \% \mathrm{~N}, \mathrm{P}$ and $\mathrm{K}$ were $3.40,0.15$ and $3.42 \%$ respectively. Humic substances derived from plant have characteristics of $\mathrm{pH} \mathrm{7.8,} \mathrm{EC} 0.78$ and $\mathrm{OM} 3.2 \% \mathrm{P}$ and $\mathrm{K}$ were 0.20 and $0.5 \%$ respectively The treatments were: Recommended Dose DAP (50 kg ha ${ }^{-1} \mathrm{HA} 1$ : Control (No humic acid) HA2: plant derived HA @7.5 mg Kg${ }^{-1}$ HA3: plant derived HA @ $15 \mathrm{mg} \mathrm{Kg}^{-1} \mathrm{HA} 4$ : coal derived HA @ $15 \mathrm{Kg} \mathrm{ha}^{-1}$ HA5: coal derived HA @ $30 \mathrm{Kg} \mathrm{ha}{ }^{-1}$. The composite soil samples were collected before experiment; air dried; sieved (2 mm). Plant samples were analyzed for NO3, availableP andsoluble $\mathrm{K}$ adopting standard analytical methods. The data thus obtained were subjected for statistical analysis using Statistic 8.1 package. The basic physical and chemical characteristics of soil under investigation were analyzed as described by ICARDA [8] standard methods and presented in table1. Soil texture class was determined according to hydrometer method as described by Bouyoucos [9]. Soil pH and ECe (1:1 soil to water ratio) were measured using digital $\mathrm{pH} / \mathrm{EC}$ meter. Plant samples collected for $\mathrm{N}$, and $\mathrm{P}$ concentration in plant tissues were dried in oven at $60^{\circ} \mathrm{C}$ till constant weight. Ground plant samples were digested in perchloric-nitric acid $(2: 1 \mathrm{NN})$ mixture [10]. Total nitrogen in mung bean was determined by the Kjeldahl procedure as described by Bremner and Mulvaney [11]. Soil samples were determined by ABDTPA method as described by Soltanpour and workman [12]. The data thus obtained were statistically analyzedaccording to Gomez and Gomez [13].

\section{RESULTS AND DISCUSSIONS}

Humic acid application on grain yield (Figure 1) showed that coal based HA at $30 \mathrm{~kg} \mathrm{ha}^{-1}$ along with $50 \mathrm{~kg} \mathrm{ha}^{-1}$ DAP recorded the highest grain yield $0.79 \mathrm{t}$ $\mathrm{ha}^{-1}$ that is $14.4 \%$ more than the treatment receiving 50 $\mathrm{kg} \mathrm{ha}^{-1}$ DAP application alone. It was followed $0.75 \mathrm{t}$ $\mathrm{ha}^{-1}$ the treatment receiving plant based HA at $15 \mathrm{mg}$ $\mathrm{kg}^{-1}$. Maximum yield statistically same with $\mathrm{HA}$ application $15 \mathrm{~kg} \mathrm{ha}^{-1}$ Similar findings have been reported by [14]. Gao et al. [15] and Akhtar et al. [16] that humic acid significantly enhance root and shoot elongation and yield mung by activating the hormonal activity It is concluded that HA have significant effect on grain yield on mungbean by enhancing nutrients availability and reducing the $P$ fixation and increases its availability through chelation effect. Therefore, increased availability of nutrients and its uptake confirmed the soil fertility improvement by humic acid addition at $15 \mathrm{~kg} \mathrm{ha}^{-1}$
Humic acid application on bio mass (Figure 2) showed that HA at $15 \mathrm{~kg} \mathrm{ha}^{-1}$ along with $50 \mathrm{~kg} \mathrm{ha}^{-1}$ DAP recorded the highest bio mass $1.7 \mathrm{t} \mathrm{ha}^{-1}$ that is $20 \%$ more than the treatment receiving $50 \mathrm{~kg} \mathrm{ha}^{-1} \mathrm{DAP}$ application alone. Similar findings have been reported by [14]. Gao et al. [15] and Akhtar et al. [16] that humic acid significantly enhance root and shoot elongation and yield mung by activating the hormonal activity It is concluded that HA have significant effect on grain yield on mungbean by enhancing nutrients availability and reducing the $P$ fixation and increases its availability through chelation effect. Therefore, increased availability of nutrients and its uptake confirmed the soil fertility improvement by humic acid addition at $15 \mathrm{~kg} \mathrm{ha}^{-1}$.

Nitrate content in the soil were affected with the interaction of HA, and DAP application. The highest concentration $\left(3.1 \mathrm{mg} \mathrm{kg}^{1}\right)$ was found with the application of $\mathrm{HA}$ at $30 \mathrm{~kg} \mathrm{ha}^{-1}$ along with $50 \mathrm{~kg}$ ha ${ }^{1}$ DAP. It was statistically at par with HA $15 \mathrm{~kg} \mathrm{ha}^{-1}$ application. An increase of $40 \%$ higher than In comparison to $100 \%$ DAP application alone (Figure 3). It was followed by the treatment at $\mathrm{HA}$ at $15 \mathrm{mg} \mathrm{kg}^{-1}$. It shows that HA application significantly reduces the unease activity led to reduce the losses of $\mathrm{N}$ volatilization as described by Vaughan and Ord [17]. Similar findings have been reported by $\mathrm{Xi}$ et al. [7] and [8].

Phosphorus content in the soil was positively affected with the interaction of HA, and DAP application. The highest concentration of soil $\mathrm{P}$ (1.37 $\mathrm{mg} \mathrm{kg}{ }^{-1}$ ) was recorded with the application of HA at $30 \mathrm{~kg} \mathrm{ha}{ }^{-1}$ along with $50 \mathrm{~kg} \mathrm{ha}^{-1} \mathrm{DAP}$ (Figure 4). However, it was statistically at par with the applicationof $\mathrm{HA}$ at $15 \mathrm{~kg} \mathrm{ha}^{-1}$ along with $50 \mathrm{~kg}$ ha ${ }^{1}$ DAPapplication. It shows that $\mathrm{HA}$ and application significantly reduces the phosphorus fixation and increases its availability through chelation effect. This is in consonance with the findings of David et al. [19] who reported slow and continuous dissolution of phosphate minerals in soil by HA increased $P$ availability. The soil phosphates activity improved by humic acid might have resulted in increased $P$ availability as phosphatase hydrolyses the phosphate esters into inorganic phosphorus Malcolm and Vaughan [17]. Heng [20] reported that HA reduces P soil fixation and hence increased $\mathrm{P}$ availability.

Nitrogen in mungbean plant was positively affected by HA Data showed that mungbean plant $\mathrm{N}$ content was increased both with HA application (Figure 5). The highest $\mathrm{N}$ concentration (3.65\%) was observed with the HA application at $30 \mathrm{~kg} \mathrm{ha}^{-1}$ along with $50 \mathrm{~kg}$ $\mathrm{ha}^{-1}$ DAP and statistically at par withHA application at $15 \mathrm{~kg} \mathrm{ha}^{-1}$ along with $50 \mathrm{~kg} \mathrm{ha}^{-1}$ DAP Similar findings have been reported Samson and Visser [21] that the increased $\mathrm{N}$ uptake was supposed to be due to the better use efficiency of applied $\mathrm{N}$ fertilizers in the presence of 
humic acid coupled with retarded nitrification process enabling the slow availability. It was reported that humic substances promote the activity of PGPR to induce the growth promoting hormones in rhizospheric zone and these hormones increase the efficiency of roots to transport water and nutrients from soil solution to plants [4].

Treatments significantly improved the $\mathrm{P}$ content in whole shoot mungbean plant at flowering stage. Results show that the highest concentration of $\mathrm{P}$ in mungbean $(0.34 \%)$ was observed in with HA application at $30 \mathrm{~kg} \mathrm{ha}^{-1}$ along with $50 \mathrm{~kg}$ ha $^{-1}$ DAP (Figure 6). However it was statistically at par with the treatment and it is at par with the applicationof HA at $15 \mathrm{~kg} \mathrm{ha}^{-1}$ along with $50 \mathrm{~kg}$ ha-1 DAP. The increase in $\mathrm{P}$ uptake ascribed to low soil $\mathrm{P}$ fixation and or formation of humophospho complexes, which are easily assimilable by the plants [22]. The HA application with $P$ fertilizer significantly increased the amount of watersoluble phosphate and strongly retard the formation of occluded phosphate, and increased $\mathrm{P}$ uptake by plants Wang et al. [23]. Xi et al. [7] also observe the stimulatory effect on plant micro and macronutrient uptake due to humic acid application. HA fertilizers enhanced the uptake and utilization of $\mathrm{N}, \mathrm{P}$ and $\mathrm{K}$ by plants compared to inorganic fertilizers $[8,24]$.

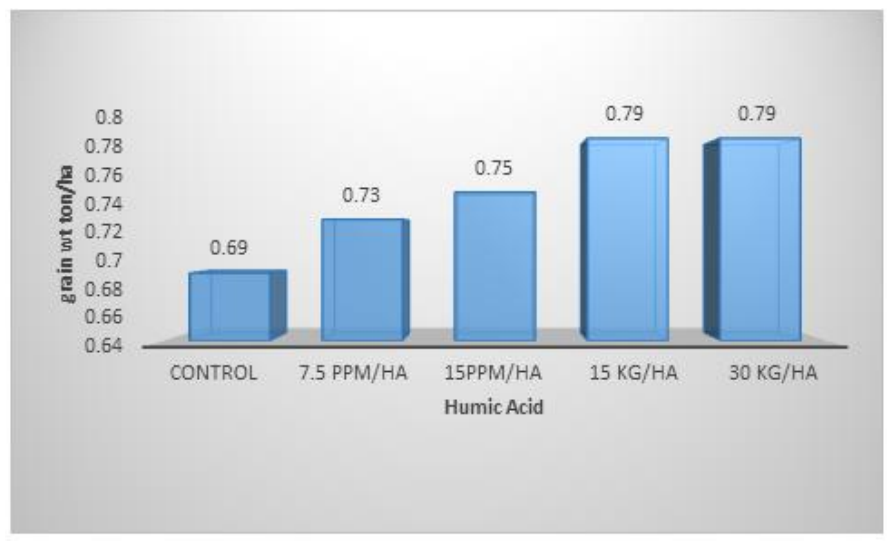

Fig-1: Mungbean yield as affected by coal and plant based HA

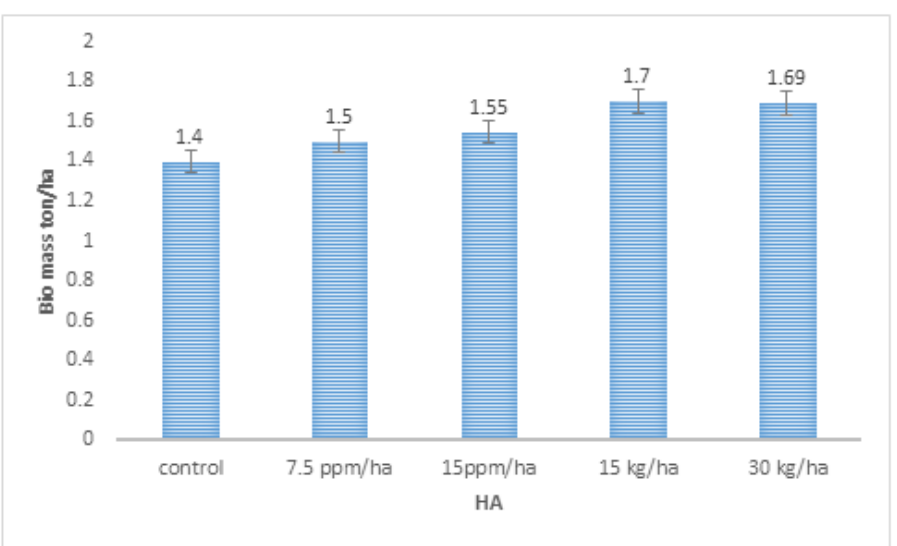

Fig-2: Mungbean bio mass as affected by coal and plant based HA

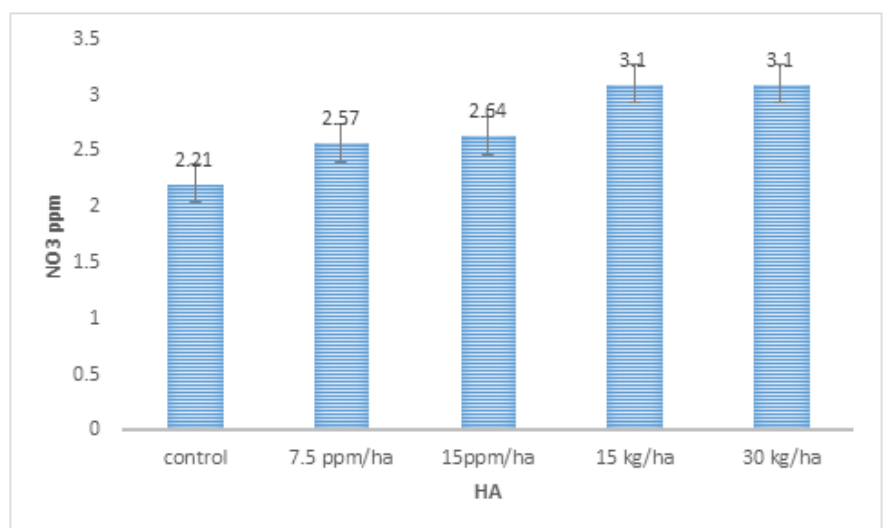

Fig-3: Residual soil $\mathrm{NO}_{3}$ as affected by coal and plant based $\mathrm{HA}$ 


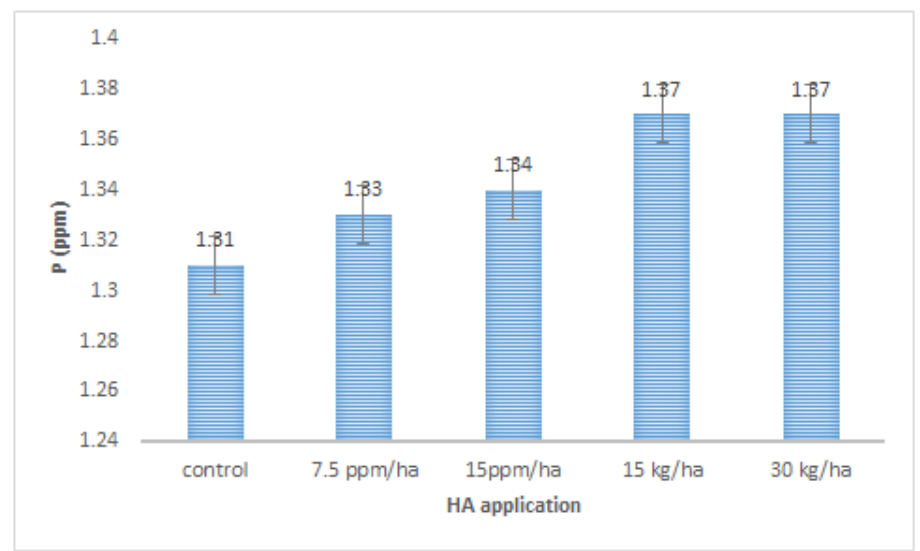

Fig-4: Residual soil available $P$ as affected by coal and plant based HA

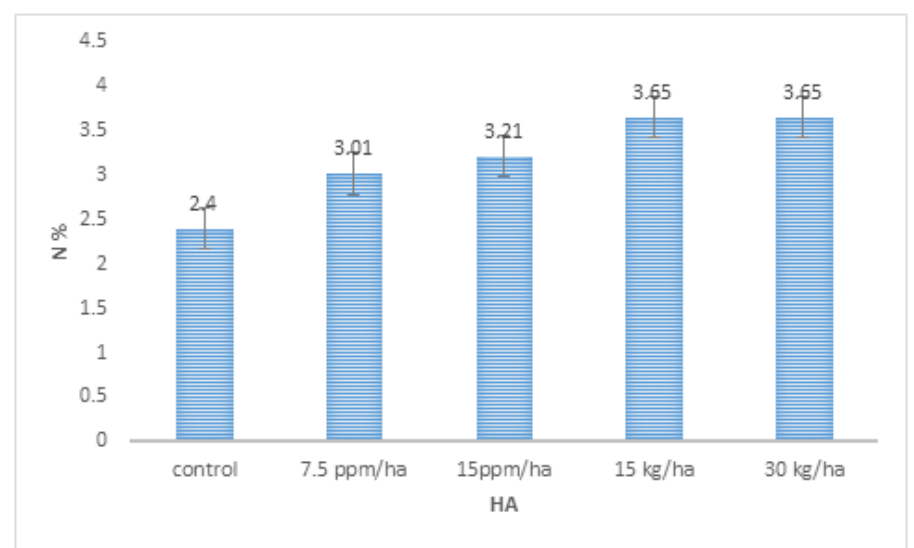

Fig-5: Plant $N \%$ as affected by coal and plant based HA

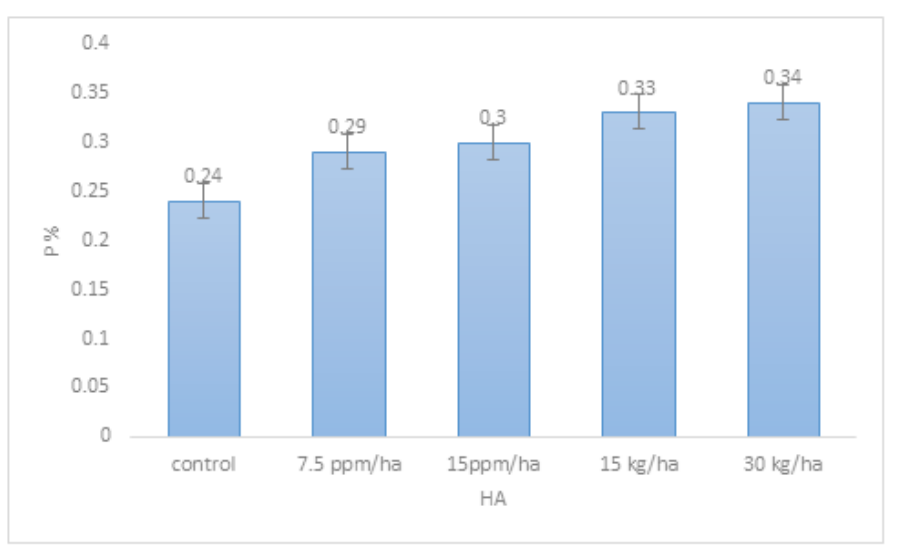

Fig-6: Plant $P$ \% as affected by coal and plant based HA

\section{CONCLUSION}

The combined effect of coal based HA at 15 $\mathrm{Kg} \mathrm{ha}^{-1}$ along with $50 \mathrm{Kg} \mathrm{ha}^{-1}$ DAP has registered not only the maximum mungbean yield $\left(0.79\right.$ ton $\left.\mathrm{ha}^{-1}\right)$ and also maximum uptake of $\mathrm{N}$ and $\mathrm{P}$ nutrients. It may be concluded that humic acid couple with inorganic fertilizer can help to improve mungbean productivity. It is also recommended more field studies may be conducted to further assess HA application for dissemination and adaptation in future.

\section{REFERENCES}

1. Bakry, B. A., Elewa, T. A., El-Kramany, M. F., \& Wali, A. M. (2013). Effect of humic and ascorbic acids foliar application on yield and yield components of two wheat cultivars grown under newly reclaimed sandy soil. International Journal of Agronomy and Plant Production, 4(6), 11251133.

2. Babhulkar, P. S., Wandile, R. M., Badole, W. P., \& Balpande, S. S. (2000). Residual effect of longterm application of FYM and fertilizers on soil properties (Vertisols) and yield of soybean. Journal of the Indian Society of Soil Science, 48(1), 89-92. 
3. Büyükkeskin, T., \& Akinci, Ş. (2011). The Effects of Humic Acid on Above-Ground Parts of Broad Bean (Vicia faba L.) Seedlings Under Al 3+ Toxicity. Fresenius Environmental Bulletin, 20(3), 539-548.

4. El-Hassanin, A. S., Samak, M. R., Moustafa, N., Shafika, A. M., Khalifa, N., \& Ibrahim Inas, M. (2016). Effect of foliar application with humic acid substances under nitrogen fertilization levels on quality and yields of sugar beet plant. International Journal of Current Microbiology and Applied Sciences, 5(11), 668-680.

5. El-Bassiouny, H. S. M., Bakry, B. A., Attia, A. A. E. M., \& Allah, M. M. A. (2014). Physiological role of humic acid and nicotinamide on improving plant growth, yield, and mineral nutrient of wheat (Triticum durum) grown under newly reclaimed sandy soil. Agricultural Sciences, 5(08), 687.

6. Daur, I., \& Bakhashwain, A. A. (2013). Effect of humic acid on growth and quality of maize fodder production. Pak. J. Bot, 45(S1), 21-25.

7. Xi, J., He, M., \& Lin, C. (2010). Adsorption of antimony (V) on kaolinite as a function of $\mathrm{pH}$, ionic strength and humic acid. Environmental Earth Sciences, 60(4), 715-722.

8. Ryan, J., Estefan, G., \& Rashid, A. (2001). Soil and plant analysis laboratory manual, International Centre for Agricultural Research in the Dry Areas (ICARDA). Aleppo and National Agricultural Research Centre (NARC), Islamabad, Pakistan.

9. Bouyoucos, G. J. (1962). Hydrometer method improved for making particle size analyses of soils 1. Agronomy journal, 54(5), 464-465.

10. Rhoades, J.D. (1982). Cation exchange capacity. In: Methods of Soil Analysis, Part 2: Chemical and Microbiological Properties, A. L. Pages, R.H. Miller and D.R. Keeney (eds.), 2nd edtion, American Society of Agronomy, Madison, Wisconsin, USA, 149-158,

11. Bremner, J.M., \& Mulvaney C.S. (1982). In. A. L. Page. (ed.).Method of soil analysis Nitrogen-total, 595- 624.

12. Soltanpour P.N., \& Workman S. (1979). Modification of the $\mathrm{NH}_{4} \mathrm{HCO}_{3}$-DTPA soil test to omit carbon black. Commun. Soil Sci. Plant Analysis. 10:1411-1420.

13. Gomez, K.A., \& Gomez A.A. (1984). Statistical Procedures for Agriculture Research. 2nd edition, John Wiley and Sons Inc., NewYork, USA.

14. Shafeek, M. R., Helmy, Y. I., Nadia, M. O., \& Rizk, F. A. (2013). Effect of foliar fertilizer with nutritional compound and humic acid on growth and yield of broad bean plants under sandy soil conditions. Journal of Applied Sciences Research, 9(6), 3674-3680.

15. Gao, T. G., Jiang, F., Yang, J. S., Li, B. Z., \& Yuan, H. L. (2012). Biodegradation of Leonardite by an alkali-producing bacterial community and characterization of the degraded products. Applied microbiology and biotechnology,93(6), 25812590.

16. Akhta, T., Ismail, S. M., \& Al-Nakhlawy, F. S. (2017). Optimization of Humic acid application rate by evaluating the response of mung was (Vigna radiata) yield, growth components and soil properties in western region of Saudi Arabia. Int. J. Biosci, 1(1), 240-248.

17. Vaughan, D., \& Ord, B. G. (1991). Influence of natural and synthetic humic substances on the activity of urease. Journal of Soil Science, 42(1), 17-23.

18. Du, H., Xue, S., \& Sun, Z. (2007). Effects of different application rates of humic acid compound fertilizer on leave nutrient accumulation and physiological mechanism of grape. Chinese Journal of Eco-Agriculture, 15, 49-51. Du, H., Xue, S., \& Sun, Z. (2007). Effects of different application rates of humic acid compound fertilizer on leave nutrient accumulation and physiological mechanism of grape. Chinese Journal of EcoAgriculture, 15, 49-51.

19. David, P. P., Nelson, P. V., \& Sanders, D. C. (1994). A humic acid improves growth of tomato seedling in solution culture. Journal of plant nutrition, 17(1), 173-184.

20. Lau, C. H. (1989). Influence of humic substances on P-sorption in some Malaysian soils under rubber.

21. Samson, G., \& Visser, S. A. (1989). Surface-active effects of humic acids on potato cell membrane properties. Soil Biology and Biochemistry, 21(3), 343-347.

22. Raina, J. N., \& Goswami, K. P. (1988). Phenolic compounds produced during decomposition of wheat straw in soils. J. Indian Soc. Soil Sci, 36, 787-90.

23. Wang, X. J., Wang, Z. Q., \& Li, S. G. (1995). The effect of humic acids on the availability of phosphorus fertilizers in alkaline soils. Soil use and management, 11(2), 99-102.

24. Akinci, S., BUeYUeKKESKIN, T., EROĞLU, A., \& ERDOĞAN, B. E. (2009). The effect of humic acid on nutrient composition in broad bean (Vicia faba L.) roots. Notulae Scientia Biologicae, 1(1), 81-87. 